\title{
FACTORS ASSOCIATED WITH NON-ADHERENCE TO HEPATITIS B VIRUS ANTI-VIRAL THERAPY
}

\begin{tabular}{|c|c|}
\hline Journal: & Antiviral Therapy \\
\hline Manuscript ID & AVT-17-OA-4217.R1 \\
\hline Manuscript Type: & Original Article \\
\hline Date Submitted by the Author: & $\mathrm{n} / \mathrm{a}$ \\
\hline Complete List of Authors: & $\begin{array}{l}\text { Sheppard-Law, Suzanne; University of Technology Sydney, Faculty of } \\
\text { Health, Building 10, level 7; Sydney Children\'s Hospital Randwick, Nursing } \\
\text { Research Unit, BA builing, level } 8 \\
\text { Zablotska-Manos, Iryna; The Kirby Insitute, UNSW Australia, } \\
\text { Kermeen, Melissa; Concord Repatriation General Hospital, } \\
\text { Gastroenterology and Liver Services } \\
\text { Holdaway, Susan; Westmead Hospital } \\
\text { Lee, Alice; Concord Repatriation General Hospital, Gastroenterology \& Liver } \\
\text { Service } \\
\text { George, Jacob; Westmead Hospital, Storr Liver Unit ; University of Sydney, } \\
\text { Westmead Institute for Medical Research } \\
\text { Zekry, Amany; St George Hospital; UNSW Australia, St George Hospital } \\
\text { Clinical Group School of Medicine } \\
\text { Maher, Lisa; The Kirby Insitute, UNSW Australia }\end{array}$ \\
\hline Keywords: & $\begin{array}{l}\text { medication adherence, chronic hepatitis } B \text {, viral hepatitis, health literacy, } \\
\text { medication routine, non-adherence, anti-viral }\end{array}$ \\
\hline
\end{tabular}




\title{
Factors associated with non-adherence to hepatitis B virus anti-viral therapy
}

\begin{abstract}
Background: Hepatitis B virus (HBV) anti-viral therapy has the potential to reduce the burden of HBV-related liver disease by suppressing HBV deoxyribonucleic acid (DNA) replication to undetectable levels, reducing the progression of liver fibrosis and reducing the risk of hepatocellular carcinoma (HCC) development. Treatment outcomes and long-term benefits require adherence to medication regimens. This study aimed to identify the prevalence and factors associated with non-adherence to anti-viral therapy. Methods: A cross-sectional survey of patients receiving HBV anti-viral therapies was conducted in three Sydney hospitals. Participants were asked to complete an online questionnaire. Logistic regression was used to assess the associations between non-adherence (defined as missing more than one day of medication in the last 30 days) and demographic, socio-economic, disease, treatment, health-care-system and individual-related factors. Results: Of the 277 participants, 66 (23.8\%) were non-adherent, missing a mean 1.7 days of medication (SD 4.8) in the last 30 days. In multivariate analysis, nonadherent behaviour declined with age (OR 0.9 95\% CI 0.97-0.99, p<0.013). Participants who reported having no established routine to take their medication (OR 5.0, 95\% CI 1.4-17.4, $\mathrm{p}<0.012)$ and having inadequate health literacy (OR 2.7, 95\%CI 1.3-5.5, $\mathrm{p}<0.007)$ were more likely to be non-adherent. Conclusion: Almost a quarter of participants in the current study were non-adherent. Adherence is potentially modifiable through person-centred education, collaborative models of patient care and interventions designed to improve health literacy and establish medication routines. Findings have the potential to improve health service delivery to patients at risk of non-adherence to HBV anti-viral therapy.
\end{abstract}

Key words: medication adherence, chronic HBV, non-adherence, routine, health literacy, viral hepatitis 
Chronic hepatitis B virus (HBV) infection is a global health problem [1,2] with an estimated 213,000 (range 175,000-253,000) Australians living with the condition [3]. HBV anti-viral therapy has the potential to reduce the burden of HBV-related liver disease [1] by suppressing HBV deoxyribonucleic acid (DNA) replication to undetectable levels, reducing the progression of liver fibrosis [4] and reducing the risk of hepatocellular carcinoma HCC development [4, 5]. Treatment outcomes and long term benefits require adherence to medication regimens. Adherent behaviour is influenced by a complex interaction of five factor domains: social and economic factors, health care system factors, disease/condition-related factors, treatment-related factors and individual factors [6]. In most chronic disease settings adherent behaviour is well researched [7-9], however adherence research in HBV has a very short history with the first study published in 2011 [10]. To date, HBV adherence studies have provided sketchy descriptions of adherent behaviour. The eight studies published to date report that between $66 \%$ and $73 \%$ of participants were $100 \%$ adherent [10-13], $66.2 \%$ of participants were $>95 \%$ adherent [14], and $70 \%$ of participants were $>80 \%$ adherent [15] to their HBV medications. Two of these studies report a mean adherence rate of $99.4 \%$ over 12 months [16] and 87.8\% (SD19.1\%) over a three-year period [10]. A decline in adherent behaviour over time was described in one study with rates decreasing from $98.1 \%$ at three months to $81.4 \%$ after 12 months $[12,17]$. This pattern of behaviour was more common in people new to therapy than in longer-term patients [10]. To date, seven studies have investigated why people miss HBV anti-viral therapy. Studies have explored limited demographic, socio-economic, disease and treatment-related factors. Only one recently published study investigated the relationship between adherent behaviour and individual-related factors [15], and another study explored the relationship between health-caresystem related factors and non-adherence [14] (Table 1). Improving HBV anti-viral therapy 
adherence rates and optimising treatment outcomes requires that clinicians gain a deeper understanding of the barriers to, and facilitators of, adherence in this patient population. Using an established evidence base definition for non-adherence [18] this study aimed to 1) measure the frequency of self-reported non-adherence to HBV anti-viral medications in the last 30 days and 2) identify predictors of self-reported non-adherence.

\section{Methods}

Population and sample

A multi-site cross-sectional survey of 277 people receiving oral HBV anti-viral therapies was undertaken in 2013-2014 in three tertiary hospitals in Sydney, Australia. Patient medical records were reviewed to determine eligibility and the first author attended each hospital clinic per week (4-6 hours) during the recruitment period. People who were unable to speak English, reported a history of hepato-cellular carcinoma or had been taking anti-viral therapy for $\leq$ six months were excluded from the study. All eligible participants $(n=398)$ were approached individually by the first author and invited to participate. Close to a third of participants approached $(\mathrm{n}=121,30.5 \%)$ declined to participate (Figure 1). A sample size of 300 patients was determined to provide adequate power to detect binary covariates that increase the odds of nonadherence by about twofold.

Lead approval for the study was granted by St Vincent's Hospital Research Office, Sydney (HREC/13/SVH/218) and site-specific approval by three hospital sites. Participants were asked to sign a written consent to complete a de-identified online adherence based questionnaire administered by the first author.

Measures 
The questionnaire was designed using a secure online data collection platform SurveyGizmo. At the time of the study, there were no validated HBV adherence-based questionnaires. Therefore, we designed our data collection tool based on data from our formative qualitative work exploring factors influencing adherent behaviour [19]. The questionnaire included demographic (8 questions), treatment-related (7questions), and disease-related (6 questions) factors and asked whether medications had been missed in the last 30 days and if ever missed, and the number of days missed. A recall time of 30 days was selected (Chesney et al. 2000). Health-care-system related (12 questions ) factors included measuring the quality of communication between a clinician (defined as doctor or registered nurse) and a patient using a validated questionnaire adapted from the University of Washington Quality of Communication (QOC) questionnaire [20]. Validated tools were used to assess Individual-related (8 questions) factors such as treatment and disease knowledge, readiness to start treatment and disclosure. Participants were also asked to complete questions to measure health literacy (six questions) [21], psychological distress and depression (10 questions) [22] and the use of alcohol and other drugs (six questions) [23].

Non-adherence definition

An evidence-based definition was determined by the authors in a previous study [18]. Combining collected cross-sectional survey data from this cohort and participant's results of virological testing determined a clinically relevant and evidence-based definition of nonadherence [18]. Various combinations of missed days and never missed days were analysed to ascertain the level of adherence and/or non-adherence most strongly associated with virological breakthrough (defined as "greater than 1 log10 [10-fold] above nadir after achieving virological response during continued treatment") [24]. Missing more than one 


\section{day of medication in the previous 30 days was most strongly associated with virological breakthrough (RR 8.3, OR 10.2 95\% CI 3.1-33.8 $\mathrm{p} \leq 0.001, \mathrm{ROC}=0.76)$ and was adopted as the definition of non-adherence for subsequent analyses. [18].}

\section{Data management and analyses}

Participant responses were entered directly into a secure online software tool used to develop questionnaires and store survey data via a secure link. At the end of study recruitment the dataset was downloaded into a master database for cleaning and recoding. All analyses were undertaken in STATA 12.0 (StataCorp, College Station, TX, USA). Exploratory analyses were conducted to inspect variable distributions.

Demographic and socio-economic factors, treatment-related factors, HBV disease-related factors and individual-related factors were assessed for univariate associations with non-adherence. Non-adherence was defined as missing more than one day of medication in the last 30 days. Variables significantly associated with non-adherence in univariate analyses $(p<0.05)$ were included in a multivariable logistic regression model. Variables were considered independent predictors of non-adherence if $\mathrm{p}<0.05$ in the final multivariate model. Multivariate models described were assessed using the Hosmer-Lemeshow goodness of fit test based on 10 categories. The Hosmer-Lemeshow goodness of fit tests were not statistically significant $(p=0.91)$ indicating no evidence of poor fit to the data.

\section{Results}

Demographic characteristics, socio-economic-related factors, disease-related factors and HBV treatment-related factors of the 277 participants are presented in Table 2. Virology results are presented in Figure 2. Health-care related factors were explored including patient education, 
hospital infrastructure, pharmacy access, quality of clinician-patient communication. Approximately two-thirds of participants $(n=193,69.7 \%)$ reported receiving pre-treatment education regarding the need to take their medication daily $(n=191,68.9 \%)$ and about the risks of missing or stopping anti-viral therapy $(n=144,51 \%)$. Forty-three participants $(15.5 \%)$ said that they had difficulty collecting medication and had run out, primarily due to the limited operating hours of their hospital-based pharmacy. The quality of communication between themselves and their clinician at their last appointment rated a mean 7.8 (SD 1.3) where a score of ten was perceived as the best imaginable quality of communication.

Our study found that individual-related factors were varied. Less than half the sample $(n=128$, 46.2\%) had adequate health literacy (defined as a score of 4-6) slightly higher than Australian data [25]. Almost all participants $(n=259,93.5 \%)$ reported knowledge that anti-viral therapy should be taken at the same time daily and $227(82 \%)$ were aware of HBV treatment benefits. In contrast, less than half $(n=116,41.6 \%)$ of the participants were aware that treatment cessation could trigger an elevation of liver enzymes and/or HBV DNA replication and a third $(\mathrm{n}=103$, $37.2 \%$ ) indicated that they did not know how long their therapy would last. A small percentage $(n=3,1 \%)$ of participants perceived anti-viral therapy to be toxic, deliberately missed medication to manage treatment related side effects or reported the need to frequently take a break from medication within the last 30 days. Participants $(n=225,81.2 \%)$ said that they had disclosed their HBV status with the majority $(n=217,96.4 \%)$ reporting that they felt supported by their family and friends. Three quarters $(n=208)$ of the sample reported that they felt ready to start anti-viral therapy. Psychological distress or depression was reported by a small number of participants $(n=38,13.7 \%)$ with 36 participants $(13.7 \%)$ reporting clinically insignificant symptoms. Moderate and severe related symptoms were unrelated to HBV. The use of alcohol and other 
drugs in this sample was lower than expected with one fifth of participants reported lifetime alcohol consumption $(n=55,19.8 \%)$ and a small number of participants reported a history of tobacco consumption $(n=30,10.8 \%)$, cannabis $(n=4,1.5 \%)$ or other illicit drug use $(n=5,1.8 \%)$.

\section{Self-reported non-adherence}

Of the 277 participants, $66(23.8 \%)$ were non-adherent, reporting that they had missed more than one day of anti-viral medication in the last 30 days. Slightly more than a third of participants $(\mathrm{n}=102,36.8 \%)$ reported that they had never missed a day of HBV anti-viral therapy. The mean numbers of single and consecutive days of anti-viral therapy missed are reported in Table 3. One in ten patients $(30,10.8 \%)$ had missed clinical appointments in the three or six months prior to questionnaire completion.

Factors associated with non-adherence to $H B V$ anti-viral therapy

Demographic characteristics, disease-related, treatment-related health care system- and individual-related factors associated with non-adherence in univariate and multivariate analyses are shown in Table 4. Controlling for factors significant at $\mathrm{p}<0.05$ in univariate analysis, multivariate analysis indicated that age (OR 0.9, 95\% CI 0.97-0.99, $\mathrm{p}<0.013)$ was associated with non-adherence. Participants who reported having no established routine to take their medication (OR 5.0, 95\%CI 1.4-17.4, $\mathrm{p}<0.012$ ) and those who had inadequate health literacy (OR 2.7, 95\%CI 1.3-5.5, $\mathrm{p}<0.007$ ) were significantly more likely to be non-adherent.

\section{Discussion}

To the best of our knowledge, this is the first study to comprehensively assess the associations between risk factors and non-adherence to HBV anti-viral therapy using an evidence based 
definition [18]. Previous studies have investigated limited demographic, treatment and diseaserelated factors. Using a comprehensive questionnaire and an evidence-based definition of nonadherence (defined as missing more than one day in the last 30 days), we found that close to a quarter of participants reported non-adherence to HBV medications in the last 30 days. This is a lower rate than that reported in previous studies which defined adherence as $>80 \%$ to $100 \%$ of medication taken in the last month $[11,14,15]$. Younger age and not having an established routine to take medication and inadequate health literacy were independently associated with non-adherence. The slightly lower prevalence of non-adherent behaviour here is possibly related to changes in clinical practice and Australian HBV clinical guidelines during the course of this study [24]. Recent published research highlighted the prevalence of non-adherence to HBV antiviral therapy $[10,12]$, and raised an awareness that non-adherence is associated with virological breakthrough $[26,27]$. Non-adherent behaviour to these medications is concerning given the risk of developing drug-related resistance, virological breakthrough and hepatic flares [28, 29]. Various factors have been associated with patients' decision to miss medication in other chronic disease settings including attitudes towards medication, inflexible clinic appointments, poor clinician-patient communication [30], illness beliefs, patient knowledge [31], and younger age $[32,33]$. Laba et al. $(2012,2015)$ suggests that the intention to miss medication is temporary and potentially reversible; however, these authors cautioned that this depends on the reasons for nonadherence, and if barriers to adherence prove intractable, non-adherent behaviour will persist $[30,34]$.

The current study found that relative decline in medication non-adherence with age was $10 \%$ per year. Findings are consistent with qualitative data and with previous studies that describe a relationship between younger age and non-adherence $[10,12,19]$. Indeed in our earlier 
qualitative study, non-adherent participants who commenced HBV treatment at a younger age $(<$ 45 years) described a period of transition and adjustment to taking medicine daily. This group of patients described the importance of establishing a routine when treatment commenced [19].

Participants with no established HBV anti-viral medication routine were more than five times more likely to be non-adherent than those who had an established medication routine. This is the first quantitative study to identify the significance of medication routines and the risk that its absence poses for non-adherence to HBV anti-viral therapy. The importance of establishing a medication routine has been previously reported in one HBV study [14] and is consistent with the broader adherence literature [35-39]. Saunders et al. (2013) described the unique nature of individual medication-taking behaviour and suggests the use of environmental cues to choreograph a set routine [40]. Establishing a routine is best made a component of individualised pre-treatment education and ongoing treatment monitoring, and may require the involvement of family members and or carers. Tailoring the use of existing interventions such as pill dispensers or mobile telephone alarms may be sufficient to improve medication adherence. The third factor independently associated with non-adherence in the current study was inadequate health literacy, which was associated with a 2.7 -fold increase in the odds of nonadherence. Previous studies have not formally measured health literacy in HBV-affected populations undergoing treatment. Language discordance [14] and ineffective communication between patients and clinicians [19] have been reported to influence adherent behaviour without measuring health literacy as a potential factor contributing to misinterpretation of key health messages. Considering that more than half of the current study population reported less than adequate health literacy and that the HBV-affected population in Australia is composed primarily of migrants from non-English-speaking HBV-endemic countries [41], it is essential that health 
care providers are universally responsive to the individual health literacy needs of their patients. An individual's ability to effectively communicate does not necessarily equate to adequate health literacy [42].The use of appropriate interpreter services may overcome communication barriers and address poor English proficiency however, such strategies will not address health literacy unless clinician's use simple language and omit complex medical jargon.

Medication adherence requires an interaction of several health literacy skills to be able to follow administering instructions and to navigate hospital infrastructure to access treatment and monitoring [41, 43-45]. It is now acknowledged that it is the responsibility of all clinicians to communicate healthcare information in a way that patients and carers understand [25]. Strategies to ensure that patients have understood instructions and how to access services are necessary to limit the risk of non-adherence. The universal use of techniques such as teach-back is a positive approach to addressing and promoting the health literacy needs of all patients and limits the barriers associated with low health literacy [46-48]. Core teach-back components include the use of simple language and avoidance of medical jargon. In addition, establishing a clinical environment conducive to building trust and collaborative relationships is recommended to enable patients and their families to disclose low literacy levels [49].

Our study had several limitations. Financial constraints prevented the translation of PICF and the study questionnaire into other languages, which limited the inclusion of participants who were unable to read or speak English. The study was reliant on participant self-report and as such is also subject to social desirability and recall bias [50], however the use of an experienced clinician interviewer not directly involved in patients' care probably reduced the influence of social desirability. The current study has several strengths and is the largest study to date to assess a comprehensive range of factors and their potential association with self-reported non- 
adherence to HBV anti-viral therapies. Demographic characteristics and multiple variables from the WHO five domains of adherence [6]: socio-economic, disease, treatment, health-caresystem- and individual-related factors such as health literacy, psychological distress and patient knowledge not previously assessed in relation to HBV, were examined in the current study. Numerous studies have described medication adherence in chronic disease settings over the last two decades, yet few studies have explored non-adherence to HBV anti-viral therapies. This study adds substantially to the limited knowledge about HBV medication adherence and identifies ways to improve nursing practice and key factors to be targeted by interventions designed to improve adherence. Focused nursing education and adherence counselling may be required to commence at a younger age to minimise the risk of developing drug related resistance or other drug cessation related complications. In addition, recommendations to improve adherence include designing a set medication routine in collaboration with patients pretreatment and the universal use of techniques to effectively communicate with patients, such as avoiding medical jargon and the use of simple language. Such strategies should enable the delivery of key treatment and adherence-related messages optimising treatment related response and health outcomes. 


\section{Acknowledgements}

This study has been partially funded by Gilead Sciences PTY LTD Australia. No authors received money for this study. 


\section{Declaration of Conflict of Interest}

The first author has no conflicts of interest to declare.

Professor Lisa Maher is supported by the award of an NHMRC Senior Research Fellowship Professor Jacob George is an advisor for ABBVIE, MSD, Gilead and Bristol-Myer Squibb

Boards 


\section{References}

1. Lavanchy D. Chronic viral hepatitis as a public health issue in the world. Best Practice \& Research in Clinical Gastroenterology. 2008;22[6]:991-1008.

2. Lavanchy D. Hepatitis B virus epidemiology, disease burden, treatment, and current and emerging prevention and control measures. J Viral Hepat. 2004;11[2]:97-107.

3. The Kirby Institute. HIV, viral hepatitis and sexually transmissible infections in Australia annual surveillance report 2015. Sydney, Australia: The Kirby Institute, UNSW Australia 2015.

4. Iloeje UH, Yang HI, Chen CJ. Natural history of chronic hepatitis B: what exactly has REVEAL revealed? Liver Int. 2012;32[9]:1333-41.

5. Suzuki Y, Suzuki F, Kawamura Y, et al. Efficacy of entecavir treatment for lamivudine-resistant hepatitis B over 3 years: histological improvement or entecavir resistance? J Gastroenterol Hepatol. 2009;24[3]:429-35.

6. WHO WHO, editor. Adherence to long term therapies:evidence for action. Switzerland2003.

7. Kardas $P$, Lewek $P$, Matyjaszczyk M. Determinants of patient adherence: a review of systematic reviews. Frontiers in Pharmacology. 2013;4.

8. Lieveld FI, Van vlerken LG, Siersema PD, Erpecum KJ. Patient adherence to antiviral treatment for chronic hepatitis B and C: A systematic review. Annals of Hepatology. 2103;12[3]:380-91.

9. Gellad WF, Grenard JL, Marcum ZA. A systematic review of barriers to medication adherence in the elderly: Looking beyond cost and regimen complexity. American Journal Geriatric Pharmacotherapy. 2011;9[1]:11-23.

10. Chotiyaputta W, Peterson C, Ditah F, Goodwin D, Lok A. Persistence and adherence to nucleos(t)ide analogue treatment for chronic hepatitis B. Journal of Hepatology. 2011;54[1]:12-8.

11. Sogni $\mathrm{P}$, Carrieri MP, Fontaine $\mathrm{H}$, et al. The role of adherence in virological suppression in patients receiving anti-HBV analogues. 2012.

12. Chotiyaputta W, Hongthanakorn $\mathrm{K}$, Oberhelman $\mathrm{R}$, et al. Adherence to nucleos(t)ide analogues for chronic hepatitis $B$ in clinical practice and correlation with virological breakthroughs. Journal of Viral Hepatitis. 2012;19:205-12.

13. Dahl TF, Cowie BC, Biggs B-A, et al. Health literacy in patients with chronic hepatitis B attending a tertiary hospital in Melbourne: a questionnaire based survey. BMC infectious diseases. 2014;14[1]:1-9.

14. Giang LS, CP. Lee, AU. Evaluation of adherence to oral anti-viral hepatitis B treatment using structured questionnaires. World J Hepatology. 2012;4:43-9.

15. van Vlerken LG, Arends P, Lieveld FI, et al. Real life adherence of chronic hepatitis B patients to entecavir treatment. Digestive and Liver Disease. 2015;47[7]:577-83.

16. Peng J, Yin J, Cai S, Yu T, Zhong C. Factors asscoiated with adhernce to nucleos(t)ide analogs in chroninc hepatitis B patients:results from a one year follow-up study. Patinet preference and adherence. 2015;9:41-5.

17. Bae JW, Guyer W, Grimm K, Altice FL. Medication persistence in the treatment of HIV infection: a review of the literature and implications for future clinical care and research. AIDS (London, England). 2011;25[3]:279-90.

18. Sheppard-Law S, Zablotska-Manos I, Kermeen M, et al. Factors associated with HBV virological breakthrough. Antiviral Therapy. 2016.

19. Polis S, Zablotska-Manos I, Zekry A, L. M. Adherence to hepatitis B anti-viral therapy: A qualitative study. Gastroenterology Nursing. in press. 
20. Engelberg R, Downey L, Curtis R. Psychometric Characteristics of a Quality of Communication Questionnaire Assessing Communication about End-of-Life Care. Journal of Palliative Medicine. 2006;9[5].

21. Weiss BD, Mays MZ, Martz W, et al. Quick Assessment of Literacy in Primary Care: The Newest Vital Sign. Annals of Family Medicine. 2005;3[6]:514-22.

22. Kessler R, Andrews G, Colpe I, et al. Short screening scales to monitor population prevalences and trends in non-specific psychological distress. Psychological Medicine. 2002;32[6]:959-76.

23. White $B$, Madden $A$, Prins $M$, et al. Assessing the feasibility of hepatitis $C$ virus vaccine trials: Results from the Hepatitis $C$ Incidence and Transmission Study- community (HITS-c) vaccine preparedness study. Vaccine. 2014;32[42]:5460-7.

24. Lok A, McMahon B. AASLD PRACTICE GUIDELINE UPDATE: Chronic hepatitis B. Hepatology. 2009;50[3].

25. Australian Commmission on Safety and Quality in Health Care. Consumers, the health system and health literacy: Taking action to improve safety and quality. Sydney, ACSQHC2013. p. 1-49.

26. Hongthanakorn C, Chotiyaputta W, Oberhelman K, et al. Virological breakthrough and resistance in patients with chronic hepatitis B receiving nucleos(t)ide analogues in clinical practice. 2011.

27. Lee M. Adherence with Use of Oral Agents in the Treatment of Chronic Hepatitis B. Current Hepatitis Reports. 2012;11[2]:70-4.

28. Kamezaki $\mathrm{H}$, Kanda T, Wu S, et al. Emergence of entecavir-resistant mutations in nucleos(t)idenaive Japanese patients infected with hepatitis B virus: virological breakthrough is also dependent on adherence to medication. 2011.

29. Wang JM, Huang Y. Acute liver failure resulting from discontinuation of nucleoside analogues in chronic hepatitis B pateints: a report of two cases. Scand J of infectious Diseases. 2013;45[2]:158-60.

30. Laba T, Lehnbom E, Brien J, Jan S. Understanding if, how and why non-adherent decisions are made in an Australian community sample: A key to sustaining medication adherence in chronic disease? Research in Social and Administrative Pharmacy. 2015;11[2]:154-62.

31. Atkins $L$, Fallowfield L. Intentional and non-intentional non-adherence to medication amongst breast cancer patients. Eur J Cancer. 2006;42[14]:2271-6.

32. Gadkari AS, McHorney CA. Unintentional non-adherence to chronic prescription medications: How unintentional is it really? Health Services Research. 2012;12[98].

33. Mukhtar O, Weinman J, Jackson SHD. Intentional Non-Adherence to Medications by Older Adults. Drugs \& Aging. 2014;31[3]:149-57.

34. Laba TL, Brien JA, Jan S. Understanding rational non-adherence to medications. A discrete choice experiment in a community sample in Australia. BMC Family Practice. 2012;13.

35. Tordoff J, Simonsen K, Thomson WM, Norris PT. "It's just routine." A qualitative study of medicine-taking amongst older people in New Zealand. Pharmacy World \& Science: PWS. 2010;32[2]:154-61.

36. Chambers JA, O'Carroll RE, Hamilton B, et al. Adherence to medication in stroke survivors: a qualitative comparison of low and high adherers. Br J Health Psychol. 2011;16[3]:592-609.

37. Kumarasamy Nea. Barriers and facilitators to antiretroviral medication adherence among patinets with HIV in Chennai, India: A qualitative study. AIS patinet care and STDs. 2005;19[8]:526-37.

38. Ryan GW, Wagner GJ. Pill taking 'routinization': a critical factor to understanding episodic medication adherence. AIDS Care. 2003;15[6]:795-806.

39. Borgsteede SD, Westerman MJ, Kok IL, et al. Factors related to high and low levels of drug adherence according to patients with type 2 diabetes. International Journal of Clinical Pharmacy. 2011;33[5]:779-87. 
40. Sanders $M$, Van Oss $T$. Using daily routines to promote medication adherence in older adults. The Americian Journal of Occupational Health. 2013;67[1]:91-9.

41. Australian Bureau of Statistics. Health Literacy, Australia 2006. Canberra: 2008 Contract No.: 4233.0 -

42. Coleman C, Kurtz-Rossi S, McKinney J, et al. The Calgary Charter on Health Literacy:Rationale and Core Principles for the Development of Health Literacy Curricula. Calgary, Canada: The Centre for Literacy, 2011.

43. Ratzan SC. Health literacy: communication for the public good. Health Promotion International. 2001;16[2]:207-14.

44. Huff C. Does your patient really understand? Hospitals \& Health Networks. 2011;85[10]:34-5, 7$8,2$.

45. Ostini R, Kairuz T. Investigating the association between health literacy and non-adherence. International Journal of Clinical Pharmacy. 2014;36[1]:36-44.

46. Cesar M. Castro M, MS; Clifford Wilson, BA; Frances Wang, MA, Dean Schillinger M. Babel Babble: Physicians' Use of Unclarified Medical Jargon with Patients. Amercian Journal of Health Behaviour 2007[31 suppl 1]:S85-S95.

47. Easton P, Entwistle VA, Williams B. Health in the 'hidden population' of people with low literacy. A systematic review of the literature. BMC Public Health. 2010;10.

48. Villaire M, Mayer G. Low Health Literacy: The Impact on Chronic Illness Management. Professional Case Management. 2007;12[4]:213-6.

49. Easton P, Entwistle VA, Williams B. How the stigma of low literacy can impair patientprofessional spoken interactions and affect health: insights from a qualitative investigation. BMC Health Service Research. 2013;13:319.

50. Hennekens C, Burning J. Statistical association and cause effect relationships. In: Mayrent S, editor. Epidemiology in Medicine. 20 ed. Philadelphia, USA: Lippincott Williams \&Wilkins; 1987. p. 30-51. 


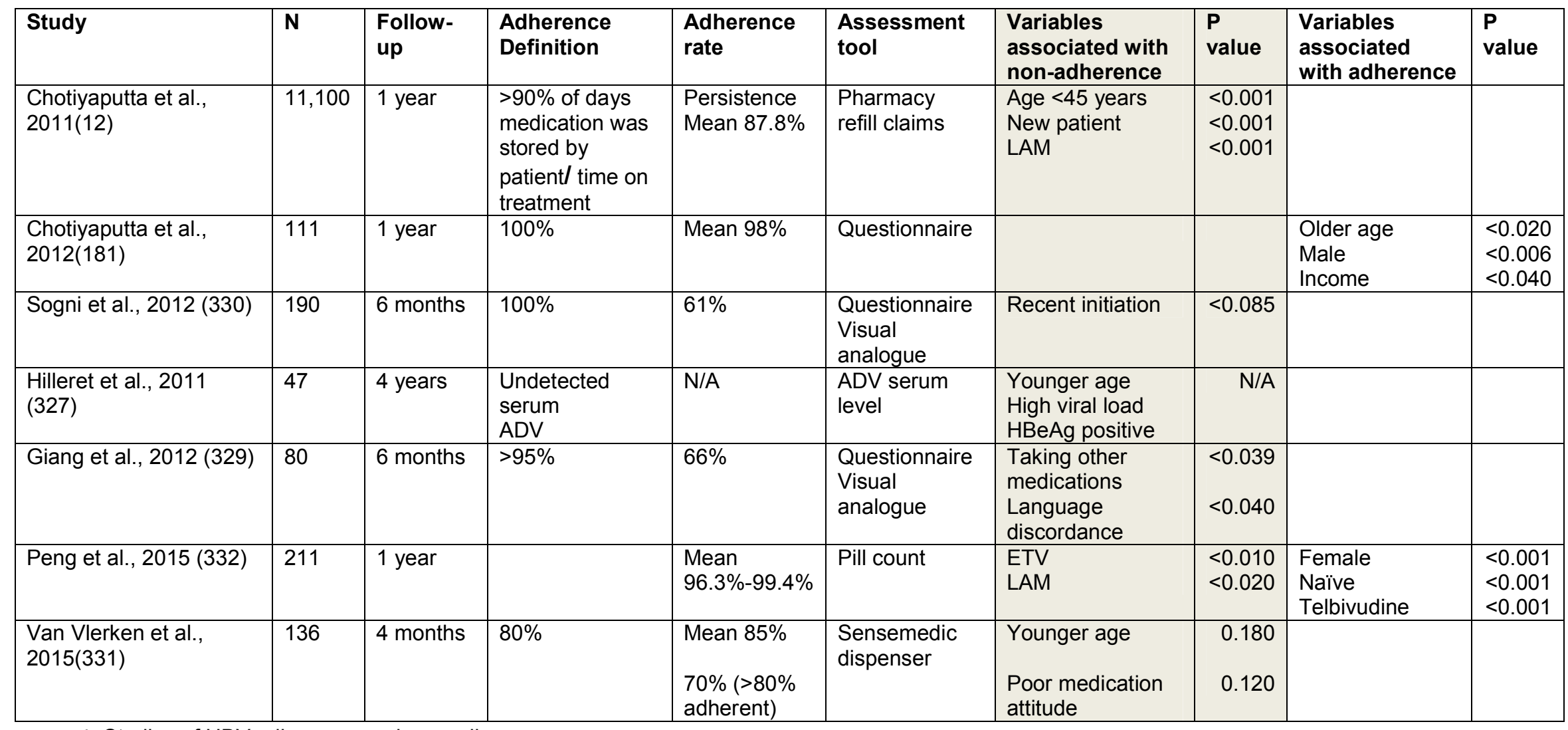

Table 1: Studies of HBV adherence and non-adherence 
Table 2: Demographic, socio-economic, HBV treatment and HBV disease-related factors

\begin{tabular}{|c|c|c|c|}
\hline Characteristics $(\mathrm{n}=277)$ & $\mathbf{N}$ & $\%$ & $\begin{array}{l}\text { Mean (SD, median, } \\
\text { range) }\end{array}$ \\
\hline \multicolumn{4}{|l|}{ Gender } \\
\hline Male & 170 & 61.4 & \\
\hline Female & 107 & 38.6 & \\
\hline Age & & & $46.5(12.7,47,20-79)$ \\
\hline \multicolumn{4}{|l|}{ Country of birth by WHO region } \\
\hline Africa & 15 & 6.16 & \\
\hline Europe & 19 & 5.69 & \\
\hline South East Asia & 23 & 9.48 & \\
\hline Western Pacific & 207 & 74.4 & \\
\hline Australia & 13 & 4.3 & \\
\hline Years living in Australia & & & $19(11.5,18,6$ mths-52) \\
\hline \multicolumn{4}{|l|}{ Preferred language spoken at home } \\
\hline English & 74 & 26.7 & \\
\hline Other language & 203 & 73.3 & \\
\hline \multicolumn{4}{|l|}{ Education } \\
\hline$\leq 10$ years & 63 & 22.7 & \\
\hline$>10$ years & 102 & 36.9 & \\
\hline University degree or higher & 112 & 40.4 & \\
\hline \multicolumn{4}{|l|}{ Income per annum } \\
\hline$\leq \$ 25,000$ (AUS) & 130 & 46.9 & \\
\hline$>\$ 25,000$ (AUS) & 147 & 53.1 & \\
\hline \multicolumn{4}{|l|}{ Current anti-viral therapy } \\
\hline ETV & 111 & 40.1 & \\
\hline TDF , & 95 & 34.3 & \\
\hline TDF \& LAM & 15 & 5.4 & \\
\hline ADV \&LAM & 9 & 5.1 & \\
\hline LAM & 14 & 3.2 & \\
\hline Don’t know & 33 & 11.9 & \\
\hline Number of HBV regiment changes regiment & & & $1.4(0.8,1,1-5)$ \\
\hline \multicolumn{4}{|l|}{ Pill burden (other than HBV) } \\
\hline No other medications & 132 & 47.7 & \\
\hline \multicolumn{4}{|l|}{$>1$ other medication } \\
\hline Years diagnosed with HBV & & & $15.9(12,14,1-79)$ \\
\hline \multicolumn{4}{|l|}{ HBeAg status } \\
\hline Negative & 163 & 60.4 & \\
\hline Positive & 70 & 25.9 & \\
\hline Borderline neg/pos & 1 & 0.4 & \\
\hline Not reported in last 12 months & 36 & 13.3 & \\
\hline \multicolumn{4}{|l|}{ Self-reported degree of liver fibrosis } \\
\hline Cirrhosis & 40 & 14.4 & \\
\hline \multicolumn{4}{|l|}{ No cirrhosis } \\
\hline Don't know & 64 & 23.2 & \\
\hline
\end{tabular}


Table 3: Self-reported non-adherence to HBV anti-viral therapy $(\mathrm{N}=277)$

\begin{tabular}{|c|r|r|r|}
\hline Adherence & $\mathbf{N}$ & $\mathbf{( \% )}$ & $\begin{array}{c}\text { Mean } \\
\text { (SD, median, range) }\end{array}$ \\
\hline $\begin{array}{l}\text { Missed more than one day of HBV } \\
\text { anti-viral therapy }\end{array}$ & & & \\
\hline No & 211 & $(76.1)$ & \\
\hline Yes & 66 & $(23.8)$ & \\
\hline $\begin{array}{l}\text { Mean number of days missed in } \\
\text { the last 30 days }\end{array}$ & & & $1.7(4.8,0,0-30)$ \\
\hline Single days & & & $5.4(7.6,2,2-30)$ \\
\hline Consecutive days & & & \\
\hline
\end{tabular}


Table 4: Demographic, disease, treatment, health-care-system and individual-related factors associated with non-adherence in univariate analyses ( $\mathrm{n}=277$ )

\begin{tabular}{|c|c|c|c|c|c|c|c|c|}
\hline \multirow[t]{2}{*}{ Adherence related factors } & \multirow{2}{*}{$\begin{array}{l}\text { Non-adherent } \\
\text { participants } \mathrm{N}\end{array}$} & \multirow[t]{2}{*}{$(\%)$} & \multicolumn{3}{|c|}{ Univariate analysis } & \multicolumn{3}{|c|}{ Multivariate analysis } \\
\hline & & & OR & $95 \% \mathrm{Cl}$ & $p$ value & OR & $95 \% \mathrm{Cl}$ & value \\
\hline Age (per year) & & & 0.9 & $0.9-1.0$ & 0.036 & 0.9 & $0.9-1.0$ & ${ }^{*} 0.013$ \\
\hline HBeAg status (229) & & & & & & & & \\
\hline Negative & $34 / 159$ & 21.3 & 1.0 & & & & & \\
\hline Positive & $24 / 70$ & 34.2 & 1.9 & $1.0-3.5$ & 0.040 & 1.8 & $0.9-3.7$ & 0.100 \\
\hline $\begin{array}{l}\text { Pre-treatment education from clinician } \\
\text { No } \\
\text { Yes }\end{array}$ & $\begin{array}{r}28 / 84 \\
38 / 193\end{array}$ & $\begin{array}{l}33.0 \\
19.6\end{array}$ & $\begin{array}{l}1.0 \\
0.5\end{array}$ & $0.3-0.9$ & 0.010 & 0.9 & $0.3-2.7$ & 0.915 \\
\hline $\begin{array}{l}\text { Adherence education (daily dose) } \\
\text { No } \\
\text { Yes }\end{array}$ & $\begin{array}{r}30 / 86 \\
36 / 191\end{array}$ & $\begin{array}{l}34.8 \\
18.8\end{array}$ & $\begin{array}{l}1.0 \\
0.4\end{array}$ & $0.2-0.8$ & 0.004 & 1.06 & $0.3-2.0$ & 0.470 \\
\hline $\begin{array}{l}\text { Education about risk of stopping medication } \\
\text { No } \\
\text { Yes }\end{array}$ & $\begin{array}{l}42 / 133 \\
24 / 144\end{array}$ & $\begin{array}{l}31.5 \\
16.6\end{array}$ & $\begin{array}{l}1.0 \\
0.4\end{array}$ & $0.2-0.8$ & 0.004 & 0.5 & $0.3-2.7$ & 0.260 \\
\hline $\begin{array}{l}\text { Problem collecting medication from pharmacy } \\
\text { No } \\
\text { Yes }\end{array}$ & $\begin{array}{r}50 / 234 \\
16 / 43\end{array}$ & $\begin{array}{l}21.4 \\
37.2\end{array}$ & $\begin{array}{l}1.0 \\
2.1\end{array}$ & $1.1-4.3$ & 0.030 & 1.9 & $0.8-4.5$ & 0.106 \\
\hline $\begin{array}{l}\text { Pre-treatment education from clinician } \\
\text { No } \\
\text { Yes }\end{array}$ & $\begin{array}{r}28 / 84 \\
38 / 193\end{array}$ & $\begin{array}{l}33.0 \\
19.6\end{array}$ & $\begin{array}{l}1.0 \\
0.5\end{array}$ & $0.3-0.9$ & 0.010 & 0.9 & $0.3-2.7$ & 0.915 \\
\hline $\begin{array}{l}\text { Knowledge: Benefits of treatment } \\
\text { Medication will control the hepatitis } \\
\text { Medication will cure my hepatitis } \\
\text { I don't know }\end{array}$ & $\begin{array}{r}48 / 227 \\
5 / 17 \\
13 / 33 \\
\end{array}$ & $\begin{array}{l}21.0 \\
29.4 \\
39.0\end{array}$ & $\begin{array}{l}1.0 \\
1.5 \\
2.4\end{array}$ & $\begin{array}{l}0.5-4.6 \\
1.1-5.2 \\
\end{array}$ & $\begin{array}{l}0.430 \\
0.030 \\
\end{array}$ & $\begin{array}{l}0.9 \\
1.2\end{array}$ & $\begin{array}{l}0.2-3.8 \\
0.5-3.4 \\
\end{array}$ & $\begin{array}{l}0.890 \\
0.630 \\
\end{array}$ \\
\hline $\begin{array}{l}\text { Established routine/set time } \\
\text { Yes } \\
\text { No it doesn't matter }\end{array}$ & $\begin{array}{r}53 / 259 \\
13 / 18\end{array}$ & $\begin{array}{l}20.5 \\
72.0\end{array}$ & $\begin{array}{c}1.0 \\
10.1\end{array}$ & $3.4-29.5$ & $\leq 0.001$ & 5.0 & $14-17.4$ & ${ }^{*} 0.012$ \\
\hline $\begin{array}{l}\text { Health literacy } \\
\text { Adequate health literacy } \\
\text { Possibly or high likelihood of low health literacy }\end{array}$ & $\begin{array}{l}19 / 128 \\
47 / 149\end{array}$ & $\begin{array}{l}14.8 \\
31.5\end{array}$ & $\begin{array}{l}1.0 \\
2.6\end{array}$ & $1.4-4.8$ & 0.001 & 2.7 & $1.3-5.5$ & ${ }^{*} 0.007$ \\
\hline $\begin{array}{r}\text { Alcohol consumption }(n=41) \\
\leq 14 \text { standard drinks per week } \\
>14 \text { standard drinks per week }\end{array}$ & $\begin{array}{l}14 / 41 \\
27 / 41\end{array}$ & $\begin{array}{l}34.1 \\
65.8\end{array}$ & $\begin{array}{l}1.0 \\
2.4\end{array}$ & $1.1-5.5$ & 0.030 & 2.4 & $0.8-6.8$ & 0.09 \\
\hline
\end{tabular}


Figure 1: Flow chart of recruitment

398 potential participants identified

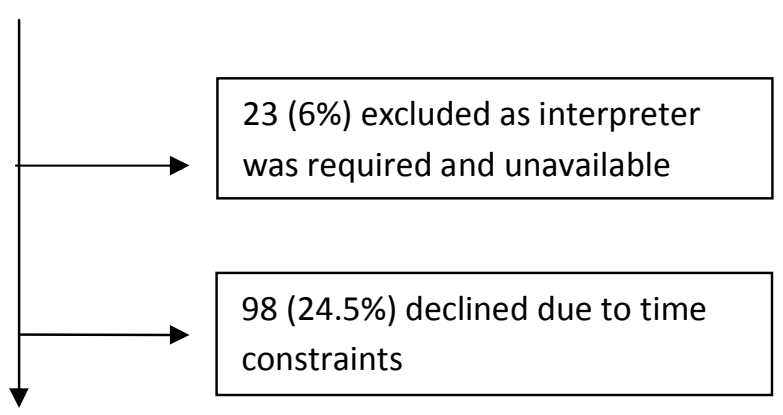

277 (69.5\%) consented to participate 
Figure 2. Flowchart of study sample virology results

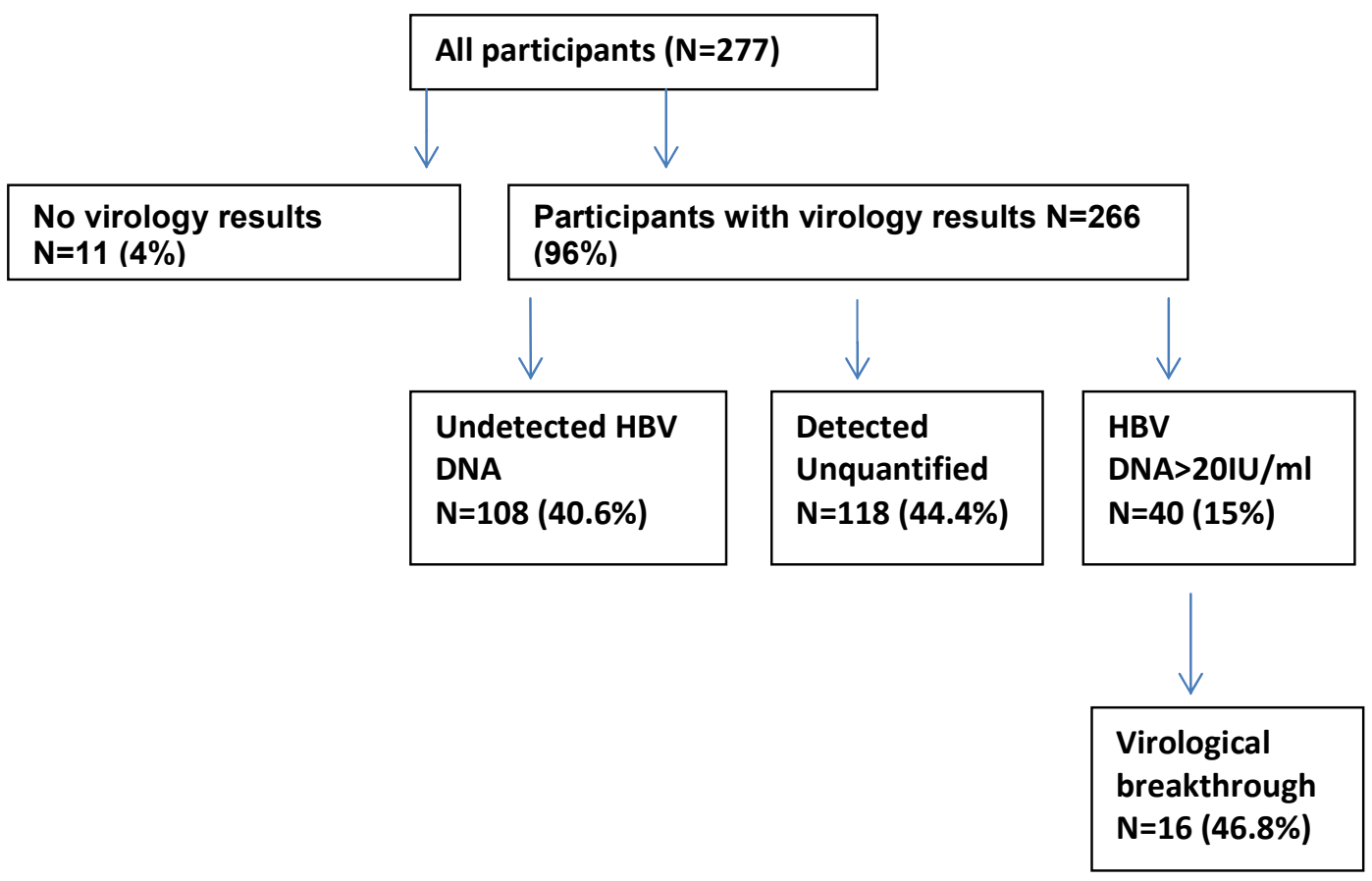

